\title{
EXTENDing The Fundamental Right OF MARRiage to SAME-SEX COUPLES: THE UNITED STATES SUPREME COURT DECISION IN OBERGEFELL V. HODGES
}

\author{
Donald H. J. HermanN*
}

The decision by the United States Supreme Court in Obergefell v. Hodges ${ }^{1}$ was greeted by newspaper headlines as an "historic ruling for gay rights" 2 and a decision mandating "equal dignity"3 for gays and lesbians. Although the Court's opinion significantly extends the right to marry to gays and lesbians, it establishes no identifiable legal doctrine on which to base further legal demands for equality outside of marriage. It is noteworthy that the Court's opinion did not rest on an analysis of the rights of gays and lesbians as a class established as litigants who deserve equal treatment because of discrimination or subjected to some level heightened scrutiny because of discrimination directed at a suspect class. ${ }^{4}$ Instead, the Court primarily based its decision on a consideration of the right to marriage as a fundamental right whose benefits could not be denied to same-sex couples since there is no justified basis for such denial. ${ }^{5}$ The Court held that same-sex couples may exercise the fundamental right to marry in all states and that there is no lawful basis for a state to refuse to recognize a lawful samesex marriage performed in another state. ${ }^{6}$ The Court's decision does have implications for gays and lesbians with regard to all the rights and benefits of marriage and family, including the adoption of children and the right to access reproductive technologies. However, the decision provides no direct legal authority to claims for protection from discrimination in employment or access to other forms of accommodation. For example, the consequence is that although gays and lesbians have the right to reveal their sexual orientation when exercising

* Donald H. J. Hermann, Professor of Law and Philosophy at DePaul University. A.B. 1965, Stanford University; J.D. 1968, Columbia University; L.L.M. 1974, Harvard University; M.A. 1979, Ph.D. 1981, Northwestern University; M.A.A.H. 1995, School of the Art Institute of Chicago; M.L.A. 2001, University of Chicago; M.A. Theology 2014, M.Div. (cand.) Catholic Theological Union.

1. 135 S. Ct. 2584 (2015).

2. Dawn Rhodes et al., Historic Ruling for Gay Rights, Court's Decision Legalizes SameSex Marriage, CHI. TRIB., June 27, 2015, at 1.

3. Equal Dignity, 5-4 Ruling Makes Same-Sex Marriage a Right Nationwide, N.Y. TIMES, June 27, 2015, at A1.

4. Cf. In re Marriage Cases, 183 P.3d 384 (Cal. 2008). In these six consolidated cases, gay and lesbian couples sought recognition of their committed relations as marriages. Plaintiffs argued that the discrimination against their relationships violated the equality guaranteed in the state constitution. Id. at 404. They argued that the discrimination was subject to strict scrutiny because the exclusion of same-sex couples from state marriage law rested upon two suspect classifications, sex or sexual orientation. $I d$. at 446 . Moreover, the refusal of a marriage license denied these gay and lesbian couples a fundamental interest in marriage. Id. The majority opinion in Obergefell focused on the latter claim.

5. Obergefell, 135 S. Ct. at 2604-05 (majority opinion).

6. Id. at 2607-08.

http://dx.doi.org/10.18060/4806.0070 
their right to marry, however, employers could terminate their employment upon learning of their sexual orientation when an employee's same-sex marriage becomes publicly known, or a hotel could deny the honeymooning same-sex couple accommodation, absent protection from discrimination provided in a minority of jurisdictions.

\section{The CourT’s OpINION}

\section{A. Formulating the Question Before the Court}

The initial issue considered by Justice Kennedy who wrote the opinion for the Court's five person majority (Justices Kennedy, Ginsberg, Breyer, Sotomayor, and Kagan) was the fact that some state statutes and constitutions defined marriage as a union between one man and one woman. ${ }^{7}$ Justice Kennedy treated the "one man and one woman" element as a traditional eligibility criterion for couples seeking to marry rather than an essential aspect of marriage which would limit it to opposite-sex partners, ${ }^{8}$ Justice Kennedy viewed "marriage" as involving "couples who wish to define themselves by their commitment to each other."

By contrast, Chief Justice Roberts in his dissent understood the fundamental right to marry as rooted in a "universal definition of marriage as the union of a man and a woman." ${ }^{\prime 10}$ Roberts charged that the Court mistakenly treated the "union of one man and one woman" as an "aspect" of marriage rather than the "core meaning of marriage [which] has endured." In response to the Chief Justice, Justice Kennedy echoed the analysis made by Justice Levinson of the Supreme Court of Hawaii in one of the earliest cases addressing the issue samesex marriage, in which that court ruled that the state's denial of marriage licenses to same-sex couples was sex discrimination under the state's Equal Rights Act. ${ }^{12}$ Justice Levinson reasoned that "definition of marriage" arguments were circular and when hundreds of legal rights and duties are at stake in claims to recognition of civil marriage, a state is required to justify its exclusion of couples from the benefit and privileges of marriage. ${ }^{13}$ Justice Kennedy took a similar position in his opinion when he wrote: "If rights were defined by who exercised them in the past, then received practices could serve as their own continued justification and new groups could not invoke rights once denied." 14

The consolidated cases before the United States Supreme Court were on

7. Id. at 2593 (citing Mich. Const. art. 1, § 25; Ky. Const. § 233A; Ohio Rev. Code $\S$ 3101.01 (2014); TENN. ConST. art. XI, § 18).

8. Id. at 2597.

9. Id. at 2600 .

10. Id. at 2613 (Roberts, C.J., dissenting).

11. Id. at 2615 (majority opinion).

12. Id. at 2596-97.

13. Baehr v. Lewin, 852 P.2d 44, 73 (Haw. 1983).

14. Obergefell, 135 S. Ct. at 2602 (majority opinion). 
appeal from the United States Court of Appeals for the Sixth Circuit, which had reversed the judgment of the federal district courts that had heard the cases and held a state had no constitutional obligation to license same-sex marriage or to recognize same-sex marriages performed out of state. ${ }^{15}$ The Supreme Court granted review on two questions: (1) whether the Fourteenth Amendment requires a state to license a marriage between two people of the same-sex, and (2) whether the Fourteenth Amendment requires an instant state to recognize a samesex marriage licensed and performed in another state when the instant state does not grant that right. ${ }^{16}$

The Court formulated the issue before it to be whether marriage was a fundamental right and determined whether the exclusion of same-sex couples from marriage was justified by an identifiable state interest. Had the Court formulated the question as to whether there is a right to "same-sex marriage" would have required the Court to determine whether "same-sex marriage" was rooted in the nation's history and traditions or, alternatively, a specific consideration of gays and lesbians as a class claiming equal protection. The importance of this initial formulation of the question may be observed in two earlier Court opinions dealing with sodomy prosecutions of homosexuals. ${ }^{17}$ In Bowers v. Hardwick, the first sodomy case decided by the Court, the question was formulated as follows: "The issue presented is whether the Federal Constitution confers a fundamental right upon homosexuals to engage in sodomy and hence invalidates the laws of the many states that still make such conduct illegal and have done so for a long time." ${ }^{18}$ In Bowers, the Court easily concluded that there was no right to engage in homosexual sodomy rooted in our legal or constitutional history. ${ }^{19}$ By way of contrast, in Lawrence v. Texas, the second sodomy case, the Court reasoned that the case involved a liberty interest (the Court did not use the term fundamental right) to engage in sexual intimacy and whether homosexuals can be denied that right. ${ }^{20}$ The Lawrence Court formulated the question in these terms: "We conclude the case should be resolved by determining whether the petitioners were free as adults to engage in the private conduct in exercise of their liberty under the Due Process Clauses of the Fourteenth Amendment to the Constitution." 21 The Court in Lawrence concluded: "When sexuality finds overt expression in intimate conduct with another person, the conduct can be but one element in a personal bond that is more enduring. The liberty protected by the Constitution allows homosexual persons the right to make their choice. ${ }^{, 22}$ From this statement, it may be seen that Lawrence not only

15. DeBoer v. Snyder, 772 F.3d 388, 388 (6th Cir. 2014).

16. Id. at 396.

17. See generally Lawrence v. Texas, 539 U.S. 558 (2003); Bowers v. Hardwick, 478 U.S. 186 (1986).

18. Bowers, 478 U.S. at 190.

19. Id. at 186 .

20. Lawrence, 539 U.S. at 558.

21. Id. at 564 .

22. Id. at 567. 
provided the methodological approach for formulating the question to be considered in Obergefell, it also presaged the decision that the relationship established by marriage involves a basic right to which same-sex couples could claim access.

\section{B. Substantive Due Process Analysis}

At its heart, the reasoning of the Court is based on substantive due process, which provides that fundamental liberties are protected under the Due Process Clause of the Fourteenth Amendment, prohibiting any state from depriving "any person of life, liberty, or property without due process of law." ${ }^{23}$ The Court in Obergefell took as its basic premise that there are fundamental liberties beyond those enumerated in the Bill of Rights that are protected by the Due Process Clause: "In addition these liberties extend to certain personal choices central to individual dignity and autonomy, including intimate choices that define personal identity and beliefs." 24

The Court identified its judicial role as identifying and protecting such fundamental liberties, not by any rigid formula, but by "exercise of reasoned judgment in identifying interests of the person so fundamental that the State must accord them its respect." 25 Although there is no rigid formula identifying such fundamental liberties, it identified history and tradition as providing guidance in this process. ${ }^{26}$ The Court found such guidance in its understanding of its previous opinions. ${ }^{27}$

The most significant precedent identified by the Court was Loving $v$. Virginia, which invalidated penal laws punishing interracial marriage. ${ }^{28}$ This decision is understood as establishing that marriage cannot be denied to interracial couples. ${ }^{29}$ Two other marriage cases are identified as recognizing a right to marriage requiring compelling state justification for exclusion of individuals from access to "one of the vital personal rights essential to the orderly pursuit of happiness by free men." ${ }^{30}$ In Turner $v$. Shafley, the right to marry could not be denied to persons in prison because the right to marry dignifies couples who wish to define themselves by their commitment to each other. ${ }^{31}$ The Court

23. U.S. Const. amend. XIV, $\S 1$.

24. Obergefell v. Hodges, 135 S. Ct. 2584, 2597 (2015) (majority opinion). The Court cites, as authority, Eisenstadt v. Baird, 405 U.S. 438, 453 (1972), and Griswold v. Connecticut, 381 U.S. $479,484-86$ (1965). These cases have particular significance since they involve the right to have access to contraception by both married couples and single individuals to prevent pregnancy (or procreation).

25. Obergefell, 135 S. Ct. at 2589.

26. Id.

27. See id.

28. Loving v. Virginia, 388 U.S. 1 (1967).

29. See id.

30. Id. at 12 .

31. Turner v. Shafley, 782 U.S. 78, 95-96 (1987). 
in Zablonki v. Redhail held that the right to marry was unconstitutionally restricted by prohibiting fathers, who were behind on child support, to marry. ${ }^{32}$

The Court conceded that its earlier opinions dealt with cases involving opposite-sex partners. ${ }^{33}$ However, the Court invoked Lawrence for the proposition that "same-sex couples have the same right as opposite-sex couples to enjoy intimate association." ${ }^{34}$ Rather than emphasizing a historical basis for the claim of same-sex partners to marry, the Court identified four principles or traditions, which establish marriage under the Constitution as fundamental, that have equal significance for same-sex couples: (1) the right to personal choice or expression of autonomy in intimate association, which "shape an individual's destiny" and "fulfills yearnings for security, safe haven, and connection," and involve personal "expression, intimacy, and spirituality"; ${ }^{35}(2)$ an association in the form of a union involving commitment and intimacy, which "dignifies couples who "wish to define themselves by their commitment to each other"",36 (3) a safeguard for families and children that provides a legal structure for family life, affording permanency and stability without which children suffer stigma, may result in uncertain family life, and whose denial can "harm and humiliate the children of same-sex couples"; $;$ (4) a recognition of families as foundational for social order, which benefits from the symbolic recognition of the union of a couple by civil society and provides material support for the household. ${ }^{38}$ The Court also identified some of the legal aspects of marital status including taxation, inheritance, spousal privilege, medical decision-making, rights and benefits of survivors, health insurance, child custody, support, and visitation. ${ }^{39}$

The Court concluded that these principles reveal no difference between same-sex and opposite-sex couples with respect to the material aspects of marriage and further observed that "[s]ame-sex couples, too, may aspire to the transcendent purposes of marriage and seek fulfillment in its highest meaning."

\section{Procreation Not Essential to Marriage}

The Court significantly omitted procreation as a central element or tenant of marriage from its litany of the significant aspects of marriage. Unabashedly the Court stated: "An ability, desire, or promise to procreate is not and has not been a prerequisite for a valid marriage in any State. ${ }^{\prime 41}$ Without specifically citing the Court's earlier opinions dealing with contraception or abortion, the Court

32. Zablocki v. Redhail, 434 U.S. 374, 384 (1978).

33. Obergefell v. Hodges, 135 S. Ct. 2584, 2598 (2015) (majority opinion).

34. Id. at 2600 .

35. Id. at 2599-00.

36. Id. at 2600 .

37. Id. at 2601 .

38. Id. at 2602-03.

39. Id. at 2601 .

40. Id. at 2602 .

41. Id. at 2601 . 
asserted: "In light of precedent protecting the right of a married couple not to procreate, it cannot be said the Court or States have conditioned the right to marry on the capacity or commitment to procreate." ${ }^{42}$ It is certainly true that sterile individuals as well as women past child-bearing age are permitted to marry. Therefore, rather that understanding procreation as an essential feature of marriage, the Court viewed procreation as a possible incident of marriage and concluded: "The constitutional marriage right has many aspects, of which childbearing is only one. ${ }^{, 43}$ It is on this point that the majority had its most significant difference with the dissenting opinion of Chief Justice Roberts, who asserted that the "universal definition of marriage as the union of a man and a woman . . . arose in the nature of things to meet a vital need: ensuring that children are conceived by a mother and father committed to raising them in the stable conditions of a lifelong relationship." ${ }^{44}$

Justice Kennedy acknowledged the significance of marriage as an ancient tradition involving a "gender-differentiated union of man and woman" in which the parties committed themselves to each other in a transformative relationship. ${ }^{45}$ Moreover, it was his identification of the "transcendent importance of marriage" that promises nobility to those who commit themselves to each other through marriage which led Justice Kennedy to identify this as the significant interest that same-sex couples have in obtaining access to marriage. ${ }^{46}$ Although Justice Kennedy later took up the question of equal protection, it is important to observe that he acknowledged the legitimacy of those in a same-sex relationship to be defined by their homosexuality, which Justice Kennedy recognized as involving an "immutable nature" that may be equated with be an immutable characteristic or trait which has played an important role in obtaining protection under the

42. Id. From the beginning of the litigation over the right of same-sex couples to marry, courts considered whether the state interest in procreation by an opposite-sex couple was a valid state interest justifying exclusion of same-sex couples from marriage. This interest was asserted by the state of Massachusetts in Goodridge v. Department of Public Health, 798 N.E.2d 941 (Mass. 2003). Chief Justice Margaret Marshall found this a justifiable state interest, but not one justifying exclusion of gay and lesbian couples from marriage:

General laws c. 207 contains no requirement that the applicants for a marriage license attest to their ability or intention to conceive children by coitus. Fertility is not a condition of marriage, nor is it grounds for divorce. People who have never consummated their marriage, and never plan to, may be and stay married. People who cannot stir from their deathbed may marry. While it is certainly true that many, perhaps most, married couples have children together (assisted or unassisted), it is the exclusive and permanent commitment of the marriage partners to one another, not the begetting of children, that is the sine qua non of marriage ....

Id. at 961 .

43. Obergefell, 135 S. Ct. at 2601.

44. Id. at 2613 (Roberts, C.J., dissenting).

45. Id. at 2594 (majority opinion).

46. Id. 
Equal Protection Clause. ${ }^{47}$ This puts the same-sex couple on par with the petitioners in Loving, in which the Court presumed race is an immutable characteristic requiring strict scrutiny when determining the equal protection claims of the litigants. ${ }^{48}$ In considering a right to marry for same-sex couples, Kennedy asserted that "their immutable nature dictates that same-sex marriage is their only real path to this profound commitment," which is only available to a couple through marriage. ${ }^{49}$

\section{Changing Concepts of Marriage and Attitudes about Homosexuality}

The Court did not view marriage as an unchanging or fixed institution, rather: "The history of marriage is one of both continuity and change ... [it] has evolved over time." ${ }^{50}$ The Court viewed the evolution from arranged marriage to marriage by choice as reflecting the understanding of marriage as a voluntary contract. ${ }^{51}$ The abandonment of the doctrine of coverture, which treated a married man and woman as a single male-dominated legal entity, was seen as reflecting a change in the status of women. ${ }^{52}$ Similarly, there have been changes in the status of gays and lesbians who are no longer treated as isolated individuals seeking sexual gratification, whose acts of intimacy are no longer deemed to be immoral and subject to criminal prosecution, and who are no longer barred from government employment, military service, or immigration because of their sexual orientation..$^{53}$ Rather than a psychiatric illness, the Court asserted that sexual orientation (homosexuality) is "both a normal expression of human sexuality and immutable. $" 54$

47. Id.; see Watkins v. U.S. Army, 847 F.2d. 1329 (9th Cir. 1988), vacated en banc, 875 F.2d. 699, 726 (9th Cir. 1989) ("[T] sometimes described the recognized suspect class as having immutable traits."). See, e.g., Parham v. Hughes, 441 U.S. 347 (1979) (describing race, national origin, alienage, illegitimacy, and gender as immutable).

48. See Loving v. Virginia, 388 U.S. 1, 11 (1967). Chief Justice Warren writing for an unanimous court: "At the very least, the Equal Protection Clause demands that racial classifications, especially suspect on criminal statutes, be subject to the most rigid scrutiny; and, if they are ever to be upheld, they must be shown to be necessary to the accomplishment of some permissible state objective ...."Id. at 11 .

49. Obergefell, 135 S. Ct. at 2594 (majority opinion).

50. Id.

51. Id.

52. Id.

53. Id. at 2596.

54. Id. In 1973, the American Psychiatric Association ("APA") eliminated the classification of homosexuality as a mental disorder from its Diagnostic and Statistical Manual of Psychiatric Disorders (DSM II) (1973). Although the APA has not used the term "immutable," in a 1998 position paper adopted by the APA Board of Directors the APA opposed any psychiatric treatment, such as "reparative" or "conversion" therapy, which assumed that homosexuality was a condition that could be cured or a trait that could be changed. Position Statement on Psychiatric Treatment 
The Court also traced the changing status and treatment of homosexuals under the Constitution. ${ }^{55}$ The Court's earliest explicit consideration of the legal status of homosexuals was in Bowers v. Hardwick, upholding the constitutionality of a state law authorizing the criminal prosecution of homosexual sodomy. ${ }^{56}$ A decade later in Romer v. Evans, the Court struck down an amendment to a state constitution that prohibited any subdivision of the state government from providing protection against discrimination based on sexual orientation. ${ }^{57}$ Then in Lawrence $v$. Texas, the Court found state criminal sodomy laws unconstitutional, overturning a same-sex sodomy conviction..$^{58}$ It is perhaps relevant that Justice Kennedy wrote the opinions for the Court in both Romer and Lawrence. ${ }^{59}$

\section{E. Developments in Legal Recognition of Same-Sex Marriage}

The Court provided a list of all state and federal decisions addressing samesex marriage, along with a list of state legislation legalizing same-sex marriage in two appendices. ${ }^{60}$ In addition, the Court identified the earliest state decisions dealing with same-sex marriage. ${ }^{61}$ The first is the 1993 decision of the Supreme Court of Hawaii in Baehr v. Lewin, holding that a law restricting marriage to opposite-sex couples involved a classification on the basis of sex, which was subject to strict scrutiny under the Hawaii Constitution. ${ }^{62}$ The Court identified the first judicial decision recognizing a right of same-sex couples to marry in 2003 by the Massachusetts Supreme Judicial Court in Goodridge v. Department

and Sexual Orientation, Am. PsychiATRIC AsS'N (1998), https://www.camft.org/images/PDFs/ SOCE/APA_Position_Statement.pdf [https://perma.cc/83VT-SJ2E?type=source].

55. See Obergefell, $135 \mathrm{~S}$. Ct. at 2596-97 (majority opinion).

56. Bowers v. Hardwick, 478 U.S. 186, 196 (1986). In its second sodomy opinion, the Court stated: "Bowers was not correct when it was decided, and it is not correct today. It ought not to remain binding precedent. Bowers v. Hardwick should be and now is overruled." Lawrence v. Texas, 539 U.S. 558, 578 (2003).

57. Romer v. Evans, 517 U.S. 620, 635-36 (1996).

58. Lawrence, 539 U.S. at 578-79.

59. See Lawrence, 539 U.S. 558; Romer, 517 U.S. 620.

60. See Obergefell, $135 \mathrm{~S}$. Ct. at 2608-11. Appendix A provides a list of all state and federal decisions addressing same-sex marriage, including separate lists of United States Court of Appeals decisions, United States District Court decisions, and state highest court decisions. Appendix B provides a list of state legislation and judicial decisions legalizing same-sex marriage.

61. Id. at 2596-97.

62. Baehr v. Lewin, 852 P.2d 44, 67 (Haw. 1993). On remand in Baehrv. Miike, No. CIV.911394, 1996 WL 694235, at*21 (Haw. Cir. Ct. Dec. 3, 1996), Judge Kevin Chang ruled that none of the state's arguments represented a compelling state interest justifying the invidious discrimination present in the state marriage law. However, a referendum amending its state constitution the state legislature was authorized to limit marriage to one man and one woman. HAW. CONST. art. $1 \S 23$. 
of Public Health. ${ }^{63}$ Additional state courts as well as a number of federal district courts and courts of appeal found states prohibiting same-sex couples from marrying to be unconstitutional. ${ }^{64}$

A significant counter or reactive response to efforts to obtain access to marriage by same-sex couples was the passage of the Defense of Marriage Act (DOMA) in 1996, which defined marriage for all federal law purposes as "only a legal union between one man and one woman as husband and wife." ${ }^{65}$ Justice Kennedy noted that the Court in 2013, in United States $v$. Windsor (again Justice Kennedy wrote the opinion of the Court), invalidated that part of DOMA, which barred the federal government from treating lawfully licensed state same-sex marriage as invalid for the purposes of federal law.${ }^{66}$ Justice Kennedy noted the Court held DOMA "impermissibly disparaged those same-sex couples "who wanted to affirm their commitment to one another before their children, their family, their friends, and their community." ${ }^{67}$ Just as Lawrence seemed to anticipate the decision in Obergefell, the Windsor opinion set out many of the interests of same-sex couples to be validated by the right to marry. ${ }^{68}$

Justice Kennedy observed that although there had been numerous opinions finding a constitutional basis for the access of same-sex couples to marriage, the principal exception was the opinion of the United States Court of Appeals for the Sixth Circuit that produced a disparity in federal case law and resulted in a division among the states on the issue of same-sex marriage. ${ }^{69}$ It was this disparity that gave rise to the instant case. ${ }^{70}$

The Court viewed the analysis of the history and tradition of marriage as significant for establishing the value of marriage, but not the identity of those who should have access to the institution. ${ }^{71}$ As discussed earlier in this Article,

63. 798 N.E.2d. 941 (Mass. 2003).

64. See Obergefell, 135 S. Ct. at 2608-10.

65. Id. at 2597 (citing 1 U.S.C. $§ 7$ (2012), invalidated by United States v. Windsor, 133 S. Ct. 2675 (2013)) (majority opinion). DOMA was enacted by Congress in reaction to the Hawaii litigation dealing with same-sex marriage in which the state supreme court decided that the state needed to provide a compelling justification to deny same-sex couples access to marriage. The reaction of Congress to the Massachusetts Supreme Judicial Court's recognition of a right to samesex marriage under the state constitution was a failed effort to pass a Federal Marriage Amendment (FMA) to the United States Constitution in 2004 which read as follows:

Marriage in the United States shall consist only of the union of a man and a woman. Neither this Constitution, nor the constitution of any state, shall be construed to require that marriage or the legal incidents thereof be conferred upon any union other than the union of a man and a woman.

S.J. Res. 30, 108th Cong. (2004).

66. Windsor, 133 S. Ct. at 2681.

67. Obergefell, 135 S. Ct. at 2597 (quoting Windsor, 133 S. Ct. at 2689) (majority opinion).

68. See Windsor, 133 S. Ct. at 2693-95.

69. Obergefell, 135 S. Ct. at 2597 (majority opinion).

70. See id. at 2584 .

71. Id. at 2593-95. 
the definition of marriage as between a man and a woman cannot be the sole basis for denying access of same-sex couples to marriage: Justice Kennedy asserted that if the right to marriage was defined by those who have been recognized in the past as having the right to marry, then the established practice could serve as the continued justification for exclusion, as new groups could not gain access to the rights to marry because of their previous denial. ${ }^{72}$ Similarly, Justice Kennedy maintained that it is a mistake to consider this a matter of a "right to same-sex marriage" rather than a "right to marry." "J3 Justice Kennedy explicitly asserted that the methodology urged by the Court's opinion in Washington v. Glucksberg - that there be a "careful description" of the fundamental rights - was inappropriate in this case. ${ }^{74}$ Here there was an explicit effort to avoid the mistake the Court made in formulating the issue in Bowers (homosexual sodomy) and instead more appropriately formulate the issue, as it did in Lawrence (intimate relations). The discussion of "intimacy" in Lawrence may be viewed as equivalent to the discussion of "marriage" in this case. Justice Kennedy reasoned: "Loving did not ask about a 'right to interracial marriage'; Turner did not ask about a 'right of inmates to marry'; and Zablocki did not ask about a 'right of fathers with unpaid child support duties to marry." "'75 Instead, Justice Kennedy maintained "each case inquired about the right to marry in its comprehensive sense, asking if there was a sufficient justification for excluding the relevant class from the right" to marry. ${ }^{76}$

The Court itself manifested the major social shift in attitudes toward gays and lesbians by accepting homosexuality as normal and immutable and endorsing the view that same-sex couples are worthy of respect. ${ }^{77}$ However, the Court recognized that others may not personally share the Court's own view. ${ }^{78}$ Nevertheless, since the issue was the legal access of same-sex couples to the fundamental right of marriage, it clearly would be wrong to give effect to that personal opposition, as it would limit marriage to opposite-sex couples and support "an exclusion that soon demeans or stigmatizes those whose own liberty is then denied." "Instead, the Court concluded that as a matter of substantive due process "same-sex couples seek in marriage the same legal treatment as oppositesex couples, and it would disparage their choices and diminish their personhood to deny them this right." 80

72. Id. at 2602 .

73. See id.

74. Id. (citing Washington v. Glucksberg, 521 U.S. 702, 721 (1997)).

75. Id.

76. Id.

77. See id. at 2584 .

78. Id. at 2602 .

79. Id.

80. Id. 


\section{F. Equal Protection and the Claim of Same-Sex Couples to Marry}

The Court proceeded with an analysis based on the Equal Protection Clause of the Fourteenth Amendment. ${ }^{81}$ Justice Kennedy did not invoke a conventional equal protection analysis; he did not define a protected class nor did he identify the characteristics that justify a specific level of scrutiny to determine whether that class has been denied some governmental benefit or been subjected to a governmental restraint without the appropriate significant justification. ${ }^{82}$ Instead, Justice Kennedy adopted an approach that identified an interconnection between Due Process Clause and Equal Protection Clause, which involved a "synergy between the two protections." ${ }^{\prime 3}$ Both clauses were viewed as supporting claims to fundamental liberties: "Rights implicit in liberty and rights secured by equal protection... [in some instances] may be instructive as to the meaning and reach of the other," although either clause "may be thought to capture the essence of the right in a more accurate and comprehensive way, even as the two Clauses may converge." ${ }^{84}$ Justice Kennedy acknowledged that the recognition of the interlocking nature of these constitutional safeguards in the context of the legal treatment of gays and lesbians strengthened the claims to a basic liberty, which was previously set out in his opinion in Lawrence. ${ }^{85}$ In Lawrence, Kennedy wrote, "Equality of treatment and the due process right to demand respect for conduct protected by the substantive guarantee of liberty are linked in important respects, and a decision on the latter point advances both interests." ${ }^{\prime 86}$

The Court identified the interconnection of liberty and equality specifically discussed in Lawrence as both explicitly and implicitly underlying previous decisions dealing with access to marriage ${ }^{87}$ The Court in Loving invalidated the prohibition on interracial marriage under the Equal Protection and Due Process

81. See id. 2602-05.

82. See id. at 2584. Although briefs filed with the Court and state, and various federal courts have employed an analysis using tiers of equal protection review, the Supreme Court has not applied the three tier analysis of rational basis, intermediate scrutiny, or strict scrutiny in gay rights cases for the last twenty-five years. In the In re Marriage Cases, 183 P. 3d. 384, 401 (Cal. 2008), the Supreme Court of California ruled that sexual orientation is a suspect classification for the same reason as race. The Ninth Circuit in Latta v. Otter, 771 F.3d 456, 468 (9th Cir. 2014), ruled that sexual orientation discrimination is a suspect class and applied heightened scrutiny to strike down the Idaho ban on same-sex marriage. The majority opinion in Obergefell lacked any mention of sex discrimination as an argument in determining the right of same-sex couples to marry. From the point of view of gay rights advocates, the failure to adopt an analysis of sexual orientation as a suspect class limits the effective use of Obergefell in expanding state and federal anti-discrimination laws in providing further protection for gays and lesbians in employment and public accommodation.

83. Obergefell, $135 \mathrm{~S}$. Ct. at 2602-03 (majority opinion).

84. Id. at 2603.

85. Id. at 2604 (citing Lawrence v. Texas, 539 U.S. 558, 575 (2003)).

86. Lawrence, 539 U.S. at 575.

87. Obergefell, $135 \mathrm{~S}$. Ct. at 2603-04 (majority opinion). 
Clauses because "restricting the freedom to marry solely because of racial classifications violates the central meaning of the Equal Protection Clause" and "classifications so directly subversive of the principle of equality at the heart of the Fourteenth Amendment, is surely to deprive all the State's citizens of liberty without due process of law." ${ }^{88}$ The Court in Zablocki directly invoked the Equal Protection Clause to invalidate a law barring fathers who were behind in childsupport payments from marrying without judicial approval; however, Justice Kennedy maintained that " $[t]$ he equal protection analysis depended in central part on the Court's holding that the law burdened a right 'of fundamental importance." ",89

It was in the denial of equal access to the benefits of marriage that the Court located the primary denial of equal protection. However, this denial of benefits was directly related to the denial of the basic right of marriage itself. ${ }^{90}$ Other precedents dealing with marriage and sex-based classifications were cited and invoked as support for the view that the Equal Protection Clause "can help to identify and correct inequalities in the institution of marriage, vindicating precepts of liberty and equality under the Constitution." ${ }^{11}$ The Court maintained that the dynamic of liberty and equal protection provides significant insight to claims of same-sex couples to marriage because: "It is now clear that the challenged laws burden the liberty of same-sex couples, and it must be further acknowledged that they abridge central precepts of equality." 92 The inequality identified by the Court was the denial to same-sex couples of all the benefit afforded to opposite-sex couples by access to marriage. ${ }^{93}$ This analysis led to the holding of the Court:

$[T]$ he right to marry is a fundamental right inherent in the liberty of the person, and under the Due Process and Equal Protection Clauses of the Fourteenth Amendment couples of the same-sex may not be deprived of that right and that liberty. The Court now holds that same-sex couples may exercise the fundamental right to marry. ${ }^{94}$

\footnotetext{
88. Id. at 2603 (citing Loving v. Virginia, 388 U.S. 1, 12 (1967)).

89. Loving, 388 U.S. at 12.

90. Obergefell, 135 S. Ct. at 2604 (majority opinion).

91. $I d$.

92. $I d$.

93. Id.

94. Id. at 2604-05 (emphasis added). By basing his opinion on the fundamental right to marry through an analysis involving the synergy of the Due Process and Equal Protection Clauses, Justice Kennedy avoided the need to find the presence of animus as an obstacle for same-sex couples to marriage. In Romer v. Evans, 517 U.S. 620 (1996), and United States v. Windsor, 133 S. Ct. 2675 (2013), Justice Kennedy determined that an animus against gays and lesbians was the basis for unjustified discrimination. Although it might be possible to find cases for animus against same-sex couples in some recent statutory enactment specifying that marriage is restricted to one man and one woman relations, the fact that generally marriage has been so limited in history precludes a convincing argument that development of traditional marriage provides any evidence toward gays
} 
The Court stated that in overruling Baker v. Nelson, where it had declined to review (for lack of a substantial federal question) a decision of the Minnesota Supreme Court finding that the state's Equal Rights Act (ERA) did not invalidate the exclusion of same-sex couples from marriage..$^{95}$ Moreover, the Court declared state laws invalid to the extent that they excluded same-sex couples from marriage. ${ }^{96}$

\section{G. The Need for Supreme Court Recognition that the Right to Marry Extends to Same-Sex Couples}

At this point, the Court's opinion may be summed up as holding that samesex couples have a fundamental right to marry with access to all the benefits bestowed by marriage. The basic argument is that if the state creates an institution such as marriage with its many legal entitlements, it must extend access to that institution to all citizens unless it has a compelling justification for excluding a class of citizens from that institution or denying them its benefits. The Court implicitly found no compelling justification to exclude same-sex couples from the benefits of marriage.

The Court proceeded to consider some of the arguments directed against its decision, including claims that its decision was a usurpation of the democratic process,${ }^{97}$ would harm traditional marriage,${ }^{98}$ and would interfere with religious liberty. ${ }^{99}$ The Court maintained there had been significant public debate on the issue including legislative enactments and extensive litigation. ${ }^{100}$ In fact, this litigation had led to a disagreement among the federal courts of appeal, which the United States Supreme Court was bound to resolve. ${ }^{101}$ More significantly, the Court maintained that there was a fundamental right at issue and it was the obligation of the Court under the Constitution to vindicate valid claims by minorities to basic rights. ${ }^{102}$

Although the Court recognized the democratic process as most often providing the appropriate process for resolving conflicts and accommodating change, when claims to individual rights are raised, it is the stated obligation of the Court to determine whether such claims entail freedom and liberties secured by the Constitution. ${ }^{103}$ When this is the case, the democratic process may be too

and lesbians whatsoever. Instead, finding that same-sex couples have a "fundamental right to marry" resulted in a shifting of the burden to the state to establish a legitimate justification for exclusion.

95. Obergefell, $135 \mathrm{~S}$. Ct. at 2605 (majority opinion).

96. Id.

97. Id. at 2605-06.

98. Id. at 2606-07.

99. Id. at 2607.

100. Id. at 2605 .

101. Id. at 2606 .

102. Id. at 2605 .

103. Id. at 2605-06. 
slow or involve denial of rights of minorities. ${ }^{104}$ According to the Court: "The idea of the Constitution was to withdraw certain subjects from the vicissitudes of political controversy, to place them beyond the reach of majorities and officials and to establish them as legal principles to be applied by the Courts."105 The Court maintained that it was deciding a legal question of constitutional dimensions and that the delay in vindicating that claim would cause harm to the same-sex couples. ${ }^{106}$ In fact, the Court referred to the specific facts of the case before it as establishing the urgency for the recognition of the fundamental right to marriage that is at stake in these cases. ${ }^{107}$

\section{H. No Threat to Traditional Marriage or Religious Liberty}

The Court found the argument that recognition of same-sex marriage will injure traditional marriage unpersuasive. ${ }^{108}$ The claim that its decision would lead to fewer opposite-sex marriages was said by the Court to be counterintuitive. ${ }^{109}$ According to the Court, the reason couples marry and have children is "based on many personal, romantic, and practical considerations; and it is unrealistic to conclude that an opposite-sex couple would choose not to marry simply because same-sex couples may do so." 110

The Court maintained that its decision did not pose any threat to religious

104. Id.

105. Id. (citing W. Va. Bd. of Ed. v. Barnette, 319 U.S. 624, 638 (1943)).

106. Id. at 2606.

107. $I d$.

108. Id. at 2606-07.

109. Id.

110. Id. at 2607. The Court did not consider the argument that the "exclusiveness" of traditional marriage may have been a factor in some individual's choice to marry. As the availability of marriage is extended to those individuals previously excluded, the special stature of traditional marriage may be eroded. Another argument is that same-sex marriage may be more unstable than opposite-sex marriage. For example, if men are more likely to be promiscuous than women, marriages of two men may be more subject to adultery or divorce. If the frequency of divorce is increased, this may have a destabilizing effect on opposite-sex marriage partners who are influenced negatively by the increased occurrence of divorce. It may be argued that even if such concerns are valid, the interest of same-sex couples in access to the fundamental right of marriage outweighs such concerns. See Stanley Kurtz, The Libertarian Question: Incest, Homosexuality, and Adultery, in Same-Sex Marriage: The Moral and Legal Debate 265-68 (Robert M. Baird \& Stuart E. Rosenbaum eds., 2 d ed. 2004). Kurtz wrote: "Gay marriage would set in motion a series of threats to the ethos of monogamy from which the institution of marriage may never recover." Id. However, Kurtz recognized that the general abandonment of the taboo against homosexuality and the claims to personal freedom by homosexuals to the right to marry justify recognition of same-sex marriage. $I d$. Kurtz concluded: "I would rather accept some disruption in family stability than go back to the days when homosexuality itself was deeply tabooed. The increase in freedom and fairness is worth it." Id. 
liberty. ${ }^{111}$ It cited the First Amendment as providing sufficient protection to religious organizations and for people to follow their religious beliefs in their family life. ${ }^{112}$ It is, however, in the area of religious practice and belief that the Court's decision is likely to raise the most significant legal disputes. Of course, no religious institution will be required to officiate or bless same-sex marriage. However, the church-related organizations involved in education, providing social services, and operating health care facilities provide likely sites for conflict with religious rejection or condemnation of same-sex marriage and the Court's decision. Anti-discrimination laws are likely to be invoked to challenge denials of employment or service such as refusals to place children with same-sex couples by an adoption agency administered by religious institutions such as the Roman Catholic Church. ${ }^{113}$ The Court recognized the likelihood of continuing open debate on the issue of same-sex marriage, but it failed to anticipate the likelihood of significant legal dispute and the enactment of freedom of conscience laws justifying exclusion or denial of service to same-sex couples. The Court, nevertheless, was clear on its priorities: although religious institutions may refuse to provide any recognition of same-sex marriage, "[ $\mathrm{t}]$ he Constitution ... does not permit the state to bar same-sex couples from marriage on the same terms as accorded to couples of the opposite sex." 114

The Court's positive response to the second question before the Court - whether the Constitution requires states to recognize same-sex marriage validly performed out of state-was logically inevitable. The Court recognized that the harm inflicted on individuals by state bans on same-sex marriage was exactly the same harm inflicted by refusal to recognize a same-sex marriage validly established in another state. ${ }^{115}$ Therefore, the Court found there was no lawful basis for a state to refuse to recognize a lawful same-sex marriage performed in another state. ${ }^{116}$

\section{The Court's Praise of Marriage}

The Court concluded with a panegyric to marriage, which it found "embodies

111. Obergefell, 135 S. Ct. at 2607 (majority opinion).

112. Id.

113. See Donald H. J. Hermann, Defending the Public Good and Traditional Society: NonScriptural Religious Objections to Same-Sex Marriage, 49 VAL. U. L. REV. 1 (2014). The Church maintained that its opposition to same-sex marriage has a natural law basis which precludes Church complicity in any recognition of same-sex marriage. Id. at 3. In Illinois, Catholic Charities discontinued operating an agency placing children in foster homes or administering adoptions rather than comply with a state requirement that agencies receiving state funding not discriminate against same-sex couples in the placement of children. See, e.g., Rockford Diocese to Discontinue Adoption Services, WIFR (May 27, 2011), http://www.wifr.com/home/headlines/Rockford_Diocese to_Discontinue_Adoption_Services_122680219.html [http://perma.cc/B4F9-C7B4].

114. Obergefell, $135 \mathrm{~S}$. Ct. at 2607 (majority opinion).

115. Id. at $2607-08$.

116. Id. at 2608 . 
the highest ideals of love, fidelity, devotion, sacrifice, and family." ${ }^{117}$ It is this encomium which was the primary focus of Justice Scalia's mocking dissent, which, for example, suggested that monogamous marriage in fact restricted the occasions for an individual to engage various partners in acts of intimacy. Justice Scalia carped that "freedom of intimacy is abridged rather than expanded by marriage. Ask the nearest hippie." 118 The Court, however, maintained that: "In forming a marital union, two people become something greater than once they were . . marriage embodies a love that may endure even past death." 119 It is marriage which the Court found to be a fundamental right that is sought by samesex couples who do not want "to be condemned to live in loneliness" as "[ $t$ ]hey ask for equal dignity in the eyes of the law" by obtaining access to the fundamental right of marriage as granted by the Court through its interpretation of the Constitution. ${ }^{120}$

\section{Dissenting Opinions}

Each of the four dissenting Justices issued an opinion joined by one or more of the other dissenting justices. ${ }^{121}$ It is not clear whether some of the dissenting justices opposed any legal recognition of same-sex marriage, but all were opposed to such recognition being established by a decision of the United States Supreme Court. ${ }^{122}$

\section{A. Dissent of Chief Justice Roberts}

1. Judicial Usurpation of Democratic Process.-Chief Justice Roberts, joined by Justice Scalia and Justice Thomas, characterized the Court's opinion as rooted in social and policy considerations, rather than legal analysis. ${ }^{123}$ The Chief Justice dismissingly denominated the majority as "[f]ive lawyers ... [who] enacted their own vision of marriage as a matter of constitutional law." ${ }^{24}$ The Chief Justice's position was that same-sex marriage was appropriately a matter for public debate to be resolved by the democratic process in legislatures, not in the courts. ${ }^{125}$ Moreover, Chief Justice Roberts took the view that the fundamental right to marry was limited by the definition of marriage as a union of a man and a woman. ${ }^{126}$ Although the "Constitution does not exact any one theory of marriage," he reasoned that it is up to the people through the democratic process

117. $I d$.

118. Id. at 2630 (Scalia, J., dissenting).

119. Id. at 2608 (majority opinion).

120. Id.

121. Id. at 2591.

122. See id. at 2611-43 (Roberts, C.J., dissenting; Scalia, J., dissenting; Thomas, J., dissenting; Alito, J., dissenting).

123. Id. at 2611 (Roberts, C.J., dissenting).

124. Id. at 2612 .

125. Id. at $2611-12$.

126. Id. at 2612 . 
to retain or change the core elements of marriage. ${ }^{127}$ According to the Chief Justice, there is no provision of the Constitution or any Court precedent that provided a legitimate basis for the Court's decision. ${ }^{128}$ Although Chief Justice Roberts defended heterosexual marriage, he asserted that his dissent "is not about whether, in my judgment, the institution of marriage should be changed to include same-sex couples," but a dissent from what he considered judicial usurpation of the democratic process. ${ }^{129}$

2. Marriage Is the Union of a Man and a Woman for Procreation.-For the Chief Justice, the issue was not, as the majority stated, the "right to marry" or "marriage equality," but "what constitutes 'marriage,' or - more precisely—who decides what constitutes "marriage'?"130 Chief Justice Roberts found the definition of marriage as the union of a man and a woman to be determinative. ${ }^{131}$ Furthermore, he endorsed the view that marriage developed to ensure that "children are conceived by a mother and father committed to raising them in the stable conditions of a lifelong relationship." ${ }^{132}$ Procreation and child rearing were seen as essential features of traditional marriage. ${ }^{133}$ The Chief Justice's analysis ignored the fact, recognized by the Court, that sterile individuals, women past child-bearing age, and bed-ridden individuals are allowed to marry. ${ }^{134}$ Married couples are not required to produce children. ${ }^{135}$ In fact a whole series of decisions of the Court support the assertion that married couples may use contraception and abortion to prevent the birth of children. ${ }^{136}$ It is true, as the Chief Justice stated,

127. Id. at 2611 .

128. Id. at 2612 .

129. Id.

130. Id.

131. Id. at 2613.

132. Id. The position taken by Chief Justice Roberts was first taken in a judicial opinion in a majority opinion of the Court of Appeals of New York in Hernandez v. Robles, 855 N.E.2d 1, 7-8 (N.Y. 2006), where Justice Smith wrote:

There are at least two grounds that rationally support the limitation on marriage [to opposite-sex couples] . . . First, the Legislature could rationally decide that, for the welfare of children, it is more important to promote stability, and to avoid instability, in opposite-sex than same-sex relationships . . . There is a second reason: The Legislature could rationally believe that it is better, other things being equal, for children to grow up with both a mother and a father . . . In sum, there are rational grounds on which the Legislature could choose to restrict marriage to couples of opposite sex.

Id.

133. Obergefell, 135 S. Ct. at 2613 (Roberts, C.J., dissenting).

134. Id. at 2601 (majority opinion).

135. Id.

136. See Carey v. Population Servs. Int'l, 431 U.S. 678 (1977) (right to abortion); Roe v. Wade, 410 U.S. 113 (1973) (right to abortion); Eisenstadt v. Baird, 405 U.S. 438 (1972) (right of individuals to use contraception); Griswold v. Connecticut, 381 U.S. 379 (1965) (right of couple to use contraception). 
that "[t]he Constitution itself says nothing about marriage," 137 but neither does the Constitution say anything directly about contraception or abortion, but there are precedents on those matters that the majority invoked to support its decision. ${ }^{138}$

Chief Justice Roberts reviewed most of the opinions cited by the majority, including Loving v. Virginia, Skinner v. Oklahoma, and Zablocki v. Redhail, and found that each of the opinions presumed a procreative element. ${ }^{139}$ The Chief Justice concluded that in all of the Court's previous decisions dealing with marriage, "the core meaning of marriage has endured." 140

The Chief Justice conceded there had been social and legal changes since Baker v. Nelson, in which the Court summarily dismissed on appeal from a state court the denial of a right to a marriage license by a gay couple. ${ }^{141} \mathrm{He}$ also acknowledged decisions of state courts based on provisions of the relevant state constitution and enactment of legislation extending the right to marry to same-sex couples. ${ }^{142}$ Nevertheless, the Chief Justice identified the issue before the Court as whether the Due Process Clause and Equal Protection Clause of the Fourteenth Amendment of the United States Constitution required the states to license and recognize marriage between same-sex couples. ${ }^{143}$ The Chief Justice maintained that the Court should uphold the Sixth Circuit's decision, which held that "petitioners had not made 'the case for constitutionalizing the definition of marriage and for removing the issue from the place it has been since the founding: in the hands of state voters." 144

3. Critique of Court's Substantive Due Process Analysis.-The Chief Justice provided a critique of the majority's substantive due process analysis. ${ }^{145}$ The Chief Justice faulted the majority for not addressing the issue of whether same-

137. Obergefell, 135 S. Ct. at 2613 (Roberts, C.J., dissenting).

138. Id. at 2599 (majority opinion).

139. Id. at 2614 (Roberts, C.J., dissenting) (citing Zablocki v. Redhail, 434 U.S. 374, 386 (1978) (holding that a deadbeat dad could not be prohibited from marriage and having children), Loving v. Virginia, 388 U.S. 1, 12 (1967) (recognizing the right of interracial couples to marry as "fundamental to our very existence and survival," which the Chief Justice stated revealed an "understanding that necessarily implies a procreative component"), and Skinner v. Oklahoma, 316 U.S. 535, 541 (1942) (holding that sterilization as a criminal punishment is not permitted because "[m]arriage and procreation are fundamental to the continued very existence and survival of the race")).

140. Obergefell, 135 S. Ct. at 2615 (Roberts, C.J., dissenting).

141. Id. (citing Baker v. Nelson, 409 U.S. 810 (1972)).

142. Id. Although the public media reported that thirty-seven states recognized marriage between same-sex partners, many of these states were mandated to do so by federal court decisions. The Chief Justice correctly reported: "In all, voters and legislators in eleven states and the District of Columbia have changed their definitions of marriage to include same-sex couples. The highest courts of five states have decreed the same result under their own Constitutions." Id.

143. Id.

144. Id. (citing DeBoer v. Snyder, 772 F.3d 388, 403 (6th Cir. 2014)).

145. See id. at 2615-18. 
sex marriage was a fundamental right by using what he asserted is the basic approach to substantive due process, which involves a claim to liberty-in this case same-sex marriage - that is so rooted in the traditions and conscience of the people of the United States that it should be ranked as fundamental and cannot be deprived without compelling justification. ${ }^{146}$

The Chief Justice engaged in a lengthy analysis of the early substantive due process cases, particularly emphasizing Lochner v. New York and its progeny. ${ }^{147}$ According to the Chief Justice, Lochner embodied a non-constitutional economic theory of freedom of contract based on the belief of the justices as to whether a law was for the public good. ${ }^{148}$ But the Court subsequently rejected that approach on the grounds that the Court does "not sit as a super-legislature to weigh the wisdom of legislation." 149

Although the Lochner approach to substantive due process had been rejected, the Chief Justice recognized that there is a valid "doctrine of implied fundamental rights." ${ }^{150}$ But, he maintained application of this doctrine required rigor in carefully formulating the right at issue and a determination of whether history and tradition supported recognition of the claim of fundamental right. ${ }^{151}$ It was the Chief Justice's view that the majority failed to adhere to the methodological approach the Court developed in analyzing claims based on substantive due process. ${ }^{152}$ According to the Chief Justice: "The majority acknowledges none of this doctrinal background ... [i]ts aggressive application of substantive due process breaks sharply with decades of precedent and returns the Court to the unprincipled approach of Lochner." 153

The Chief Justice challenged the majority's interpretation of past precedent as establishing a fundamental right to marry that provided that anyone who wants to marry has a constitutional right to marry. ${ }^{154}$ According to the Chief Justice, the previous cases did not determine who could marry, but instead those cases required a state to justify barriers to marriage as marriage is traditionally understood to be a union of a man and a woman. ${ }^{155}$

According to the Chief Justice, Loving involved racial restrictions on

146. Id. at 2616 (citing Snyder v. Massachusetts, 291 U.S. 97, 105 (1934)).

147. See id. at 2617-19 (citing Lochner v. New York, 198 U.S. 45 (1905) (declaring unconstitutional a law that imposed a limit on the number of hours bakers could work)).

148. Id. at 2617.

149. Id. (citing Daybrite Lighting, Inc. v. Missouri, 342 U.S. 421, 423 (1952)). Moreover, the Chief Justice maintained that it has become an accepted rule that the Court will not hold laws unconstitutional simply because it found them "unwise, improvident, or out of harmony with a particular school of thought." Id. at 2617-18. (quoting Williamson v. Lee Optical of Okla., Inc., 348 U.S. 483, 488 (1955)).

150. Id. at 2618 (Roberts, C.J., dissenting).

151. Id.

152. Id. at 2618-19.

153. Id.

154. Id. at 2619 .

155. Id. 
marriage, Zablocki involved restrictions based on failure to provide child support, and Turner involved restriction based on status as a prisoner. ${ }^{156}$ According to the Chief Justice: "None of the laws at issue in those cases purported to change the core definition of marriage as the union of a man and a woman." 157 This analysis led him to the conclusion that while restrictions on marriage may be found constitutionally invalid, it was another matter to make a state change its definition of marriage, which is beyond the purview of the Court and appropriate interpretation of the Constitution. ${ }^{158}$

The Chief Justice dismissed the Court's reliance on the contraception cases, maintaining that the opinions in those cases rested on concern about invasions of "marital bedrooms" (Griswold v. Connecticut) and "the right to be let alone" (Eisenstadt v. Baird). ${ }^{159}$ Moreover, according to the Chief Justice, Lawrence should be properly viewed as a case involving governmental invasion of privacy. ${ }^{160}$ According to the Chief Justice, all these cases involved government intrusions which were found not to be constitutionally justified. ${ }^{161}$ However, this case involved the recognition of an affirmative claim to a right, not an objection to governmental intrusion into a right.

The Chief Justice maintained that the same-sex marriage case involved neither restrictions on marriage nor intrusions into private relationships. ${ }^{162} \mathrm{He}$ concluded, "the privacy cases provide no support for the majority's position."163 According to the Chief Justice, "although the right to privacy recognized by our precedent certainly plays a role in protecting the intimate conduct of same-sex couples, it provides no affirmative right to redefine marriage and no basis for striking down the laws at issue here." ${ }^{64}$ As will be discussed later in this Article, this assertion is at odds with the view of another dissenting justice (Scalia) who asserted in his dissent in Lawrence, "[t]his case 'does not involve' the issue of homosexual marriage only if one entertains the belief that principle and logic have nothing to do with the decisions of this Court."165

According to the Chief Justice, the methodological error of the majority was that the asserted failure to formulate the right at stake narrowly as the "right to same-sex marriage" violated the method for determining fundamental rights for

156. $I d$.

157. Id.

158. $I d$.

159. Id. at 2620 (citing Eisenstadt v. Baird, 405 U.S. 438, 453-54 (1972); Griswold v. Connecticut, 381 U.S. 479, 485 (1965)).

160. Id. It should be noted, however, that the Court in Lawrence found a liberty interest in intimate relations rather than rooting its holding in the right to privacy. Lawrence v. Texas, 539 U.S. 558, 578 (2003).

161. Obergefell, $135 \mathrm{~S}$. Ct. at 2619-20.

162. Id. at 2620 .

163. Id.

164. Id.

165. Lawrence, 539 U.S. at 605 (Scalia, J., dissenting). 
purposes of a substantive due process analysis as established in Glucksberg. ${ }^{166}$ Moreover, the Chief Justice viewed the Court's broad assertion that there is a right to "define and express" one's identity or that, "the right to personal choice regarding marriage was inherent in the concept of individual autonomy,"167 as adopting the expansive philosophical approach of Lochner, which it subsequently and unequivocally rejected. ${ }^{168}$ In Lochner, the Court invoked the economic philosophy of market capitalism; in this case, the Court adopted a philosophical approach supporting individual sexual freedom and recognition of the validity of same-sex relationships. This led the Chief Justice to the conclusion that "today's decision rests on nothing more than the majority's own conviction that same-sex couples should be allowed to marry because they want to, and that 'it would disparage their choices and diminish their personhood to deny them the right.",169

The Chief Justice questioned whether implicit in the majority's approach there was any reason to limit marriage to two persons. ${ }^{170}$ According to the Chief Justice, embracing of same-sex marriage in the face of history and tradition was greater than a move from two-person unions to plural unions which are even today recognized in other cultures. ${ }^{171}$ The Chief Justice pointed out that if the stigma experienced by children was a reason for extending the right to marry in cases of same-sex parenting families, children with plural parents should be viewed as having an equal concern to avoid the same stigma as children with same-sex parents. ${ }^{172}$

4. Critique of Court's Equal Protection Analysis.-The Chief Justice faulted the majority for failing to employ the recognized methodology for analyzing claims of discrimination in denial of basic rights. ${ }^{173}$ The Chief Justice observed that the majority's approach to equal protection lacked "anything resembling our usual framework for deciding equal protection cases . . . in which judges ask whether the classification the government is using is sufficiently related to the goals it is pursuing." ${ }^{174}$ Rather, the majority identified a " "synergy between' the Equal Protection Clause and the Due Process Clause," leading to the conclusion that the Equal Protection Clause provided an alternative basis for its holding. ${ }^{175}$ The Chief Justice maintained that "the majority fails to provide even a single sentence explaining how the Equal Protection Clause supplies independent

166. See Obergefell, 135 S. Ct. at 2620-21 (Roberts, C.J., dissenting).

167. Id. at 2589 (majority opinion).

168. See id. at 2621 (Roberts, C.J., dissenting) (citing Lochner v. New York, 198 U.S. 45, 58 (1905) (noting "the general right of an individual to be free in his person and in his power to contract in relation to his own labor")).

169. Id.

170. Id. at 2621-22.

171. Id. at 2621 .

172. Id. at 2622 .

173. Id. at 2623 .

174. Id.

175. Id. 
weight for its position." $" 176$

The Chief Justice argued there was no Equal Protection violation because the ability to procreate effectively distinguished opposite-sex couples from same-sex couples ${ }^{177}$ so that the marriage laws limited to a man and a woman were rationally related to the state's "legitimate state interest" in preserving the traditional institution of marriage. ${ }^{178}$ It is clear that the Chief Justice's argument depended on the premise that procreation is an essential element of marriage, a premise that the majority challenged. According to the Chief Justice, the other features of marriage - love, affection, mutuality, care, and companionship - were all ancillary benefits that accompanied marriage as defined by the state. ${ }^{179}$

The Chief Justices went on to identify possible negative consequences following from the Court's decision. ${ }^{180}$ These included the erosion of the Court's legitimacy as a result of "the majority's extravagant conception of judicial supremacy," which usurped the democratic process. ${ }^{181}$ Because the Court lacked the ability to deal with ancillary matters that were raised by same-sex marriage, he argued the rights of others would be affected, as "[t]oday's decision, for example, creates serious questions about religious liberty."182 The Chief Justice expressed significant concern on how recognition of same-sex marriage would affect religiously-affiliated institutions such as religiously sponsored schools and social service agencies. ${ }^{183}$

Finally, the Chief Justice faulted the rhetoric of the majority's opinion for disparaging those who oppose same-sex marriage and implying that opponents of same-sex marriage are bigots and are not fair minded. ${ }^{184}$ According to the Chief Justice, this was an effect of the overreaching Court, by which it imposed the personal view of five justices on matters of sexuality that "had nothing to do with the Constitution." 185

\footnotetext{
176. Id.

177. See id. at 2613-14.

178. Id. at 2623 .

179. See id. at 2613-14.

180. See id. at 2624-26.

181. Id. at 2624 .

182. Id. at 2625 .

183. Id. at 2625-26. The Chief Justice recognized that:

Hard questions arise when people of faith exercise religion in ways that may be seen to conflict with the new right to same-sex marriage — when, for example, religious colleges provide married students housing only to opposite-sex married couples, or a religious adoption agency declines to place children with same-sex married couples ... [and] the tax exemptions of some religious institutions would be in question if they opposed same-sex marriage.
}

Id. at 2626 .

184. Id.

185. Id. 


\section{B. Dissent of Justice Scalia}

1. Concern with Proper Role of the Judiciary.-Justice Scalia in his dissent (joined by Justice Thomas) immediately declared that the subject of the case, same-sex marriage, was of little significance to him and it received almost no consideration in his dissent. ${ }^{186} \mathrm{He}$ wrote, "[t]he substance of today's decree is not of immense personal importance to me." ${ }^{187}$ The reason for this bold statement may be the views he earlier expressed in his dissent in Lawrence, which will be discussed later in this Article. Instead, Justice Scalia focused his attention on the issue of the proper role of the judiciary in interpreting the Constitution. ${ }^{188} \mathrm{He}$ then went on to offer a scathing critique of the style of the majority's opinion, which he viewed as "pretentious" in style, "egotistic" in content, and setting out "showy profundities" which reflect the predilections of the justices in the majority. ${ }^{189}$

In his dissent, Justice Scalia expressed concern for the future of democracy, which he believed is threatened by judicial activism. ${ }^{190}$ Issues of policy such as same-sex marriage are viewed properly as matters of public debate. ${ }^{191}$ For Justice Scalia, the Constitution established a federal system in which the subject of the regulation of domestic relations is the province of the states. ${ }^{192}$ Moreover, the Fourteenth Amendment, which was at the heart of the Court's decision, was not meant to give the judiciary the power to alter traditional institutions such as marriage. ${ }^{193}$ Ultimately, Justice Scalia maintained that the majority's opinion was not a statement of law, but instead, a public policy statement resulting in the Court's ruling being "an opinion lacking even a thin veneer of law." ${ }^{194}$ Justice Scalia maintained the Court's decision was no more than "a naked judicial claim to legislative - indeed, super-legislative - power," which he asserted is at odds with the Constitution. ${ }^{195}$ Democratic governance was undermined by the Court's opinion, according to Justice Scalia, because the kind of judicial activism represented by the Court's decision was rendered by a wholly unrepresentative group of individuals, which he attempted to show as elite and from a restricted segment of American society. ${ }^{196}$

2. Critique of the Style of the Majority Opinion.-The second part of Justice Scalia's dissent focused on his criticism of the style of the Court's opinion,

186. See id. at 2626-31 (Scalia, J., dissenting)

187. Id. at 2626.

188. See id. at 2627.

189. Id. at 2630.

190. See id. at 2626-29.

191. Id. at 2627.

192. Id. at $2627-28$.

193. Id. at 2628.

194. Id.

195. Id. at 2629.

196. See id. 
which he viewed as infected by judicial "hubris."197 Surprisingly, Justice Scalia's critique itself adapted a style that at best can be described as idiosyncratic. A quote from this section of the dissent captured the eccentric style adopted in place of the usual logical style of rhetoric characteristic of judicial opinions. Justice Scalia opined:

Rights, we are told, can "rise ... from a better informed understanding of how constitutional imperatives define a liberty that remains urgent in our own era." (Huh? How can a better informed understanding of how constitutional imperatives [whatever that means] define [whatever that means] an urgent liberty [never mind], give birth to a right?). ${ }^{198}$

The gist of Justice Scalia's criticism is that the substantive due process analysis failed to conform to the accepted methodological analysis and instead reflected "the majority's likes and dislikes." 199

3. Justice Scalia's Dissent in Lawrence Anticipating Recognition of SameSex Marriage.-One reason that Justice Scalia forewent any discussion of the actual issue before the Court, "marriage of same-sex couples," may be explained by recalling his discussion in Lawrence $v$. Texas where he stated that the logical implication of the Court's opinion in that case was recognition of same-sex marriage. ${ }^{200}$ After arguing that it was not unconstitutional for a state to prosecute same-sex relations on the basis of majoritarian moral disapproval, Justice Scalia maintained that the Court's recognition of same-sex couples' right to intimate sexual relations legally and logically entailed the right of same-sex marriage despite the majority's disavowal of that position in its Lawrence opinion. ${ }^{201}$ In his dissent in Lawrence, Justice Scalia wrote

The Court says that the present case "does not involve whether the government must give formal recognition to any relationship that homosexual persons seek to enter." Do not believe it. More illuminating than this bald, unreasoned disclaimer is the progression of thought displayed by an earlier passage in the Court's opinion, which notes the constitutional protections afforded to "personal decisions relating to marriage, procreation, contraception, family relationships, child rearing, and education," and then declares that "[p]ersons in a homosexual relationship may seek autonomy for these purposes, just as heterosexual persons do." Today's opinion dismantles the structure of constitutional law that has permitted a distinction to be made between heterosexual and homosexual unions, insofar as formal recognition in marriage is concerned. $^{202}$

197. See id. at 2629-31.

198. Id. at 2630 .

199. See id. at 2630-31.

200. See Lawrence v. Texas, 539 U.S. 558, 604-06 (2003) (Scalia, J., dissenting).

201. Id. at 604-05.

202. Id. at 604 . 
Justice Scalia's view reflected the fact that the long-standing objection to samesex marriage was the underlying condemnation of homosexual acts as immoral. ${ }^{203}$ For example, the Roman Catholic Church's condemnation of same-sex marriage was based on the fact that homosexual unions are likely to involve homosexual sexual acts, which are viewed as immoral because they are closed to the possibility of reproduction and do not proceed from a genuine sexual complementarity. ${ }^{204}$ Justice Scalia conceded in his Lawrence dissent that without legal condemnation (based on moral judgment) of homosexuality, there was no justification for denial of marriage to same-sex couples. ${ }^{205}$ In his Lawrence dissent, Justice Scalia reasoned:

If moral disapprobation of homosexual conduct is "no legitimate state interest" for purposes of proscribing that conduct, and if, as the Court coos (casting all pretense of neutrality) "[w]hen sexuality finds overt expression in intimate conduct with another person, the conduct can be but one element in a personal bond that is more enduring," what justification could there possibly be for denying the benefits of marriage to homosexual couples exercising "[ $\mathrm{t}]$ he liberty protected by the Constitution." 206

As to the justification of the centrality of procreation to civil marriage, Justice Scalia summarily dismissed it as an exclusion of same-sex couples from marriage; he asserted: "Surely not the encouragement of procreation, since the sterile and elderly are allowed to marry." ${ }^{207}$ It seems clear why Justice Scalia avoided discussion of the issue at stake in Obergefell, not because it was of no "personal importance" to him, but because he was hoisted on his own petard by his dissent opinion in Lawrence. In fact, his opinion in Lawrence may be viewed as an outline for the Court's opinion in Obergefell.

\section{Dissent of Justice Thomas}

1. Liberty and the Role of Government.-Justice Thomas in his dissent (joined by Justice Scalia) focused principally on his understanding of liberty and the role of government. ${ }^{208}$ Justice Thomas began his dissent with the premise that liberty should be understood as freedom from governmental action, not entitlement to governmental benefits. ${ }^{209}$ Justice Thomas rejected the validity of

203. See id. at 604-05.

204. Joseph C. Ratzinger \& Angelo Amato, Congregation for the Doctrine of the Faith: Considerations Regarding Proposals to Give Recognition to Unions Between Homosexual Persons, VATICAN (2003), http://www.vatican.va/roman_curia/congregations/cfaith/documents/ rc_con_cfaith_doc_20030731_homosexual-unions_en.html [http://perma.cc/5MBV-F3DW].

205. Lawrence, 539 U.S. at 604 (Scalia, J., dissenting).

206. Id. at 604-05.

207. Id. at 605 .

208. See Obergefell v. Hodges, 135 S. Ct. 2584, $2631-40$ (2015) (Thomas, J., dissenting).

209. Id. at 2631 . 
substantive due process because it departed from the text of the Constitution. ${ }^{210}$ But he maintained that even under substantive due process, there was no basis for a claim in liberty by same-sex couples to marry. ${ }^{211}$ According to Justice Thomas, "liberty" should be understood in terms of physical restraint; or if understood more broadly, liberty should be understood as freedom from government action, not a right to a particular government entitlement. ${ }^{212}$

According to Justice Thomas, the claims of same-sex couples in the instant case had nothing to do with liberty guaranteed by the Constitution since they had not been "imprisoned or physically restrained by the States for participating in same-sex relationships." ${ }^{13}$ In fact, same-sex couples had freedom to co-habit, raise children, hold marriage ceremonies, travel, and establish homes where they wished without any access to marriage. ${ }^{214}$ According to Justice Thomas, the same-sex couples involved in these cases before the Court were not asking for removal of restrictions on their liberty, but they were asking for access to the privileges and benefits of marriage. ${ }^{215}$ This demand to receive benefits, according to Justice Thomas, had nothing to do with liberty properly understood, as "receiving governmental recognition and benefits has nothing to do with any understanding of 'liberty' that the Framers would have recognized." 216

2. Lack of Precedent for and Dangers Created by Recognition of Right to Same-Sex Marriage.-Justice Thomas proceeded to analyze the principal marriage precedents relied on by the majority as involving punishment or privations of couples rather than establishing a right to marry or a right to access to marriage. ${ }^{217}$ Loving is viewed as involving criminal prosecution for cohabiting. ${ }^{218}$ Zablocki v. Redhail is understood as involving a man who was threatened with a criminal penalty for remarrying because of his outstanding child support obligations. ${ }^{219}$ And Turner $v$. Safley was said to involve state inmates who were deprived of the opportunity of marrying without the permission of the superintendent of the prison. ${ }^{220}$

According to Justice Thomas's strained reading of these precedents dealing with marriage, the denial of access to the right of marriage with access to its benefits and privileges was not the issue, stating: "In none of those cases were individuals denied solely governmental recognition and benefits associated with marriage. $" 221$

210. Id

211. Id. at 2632 .

212. Id. at 2634 .

213. Id. at 2635.

214. $I d$.

215. Id. at $2635-36$.

216. Id. at 2636.

217. See id.

218. Id. (citing Loving v. Virginia, 388 U.S. 1 (1967)).

219. Id. at 2637 (citing Zablocki v. Redhail, 434 U.S. 374 (1978)).

220. Id. (citing Turner v. Safley, 482 U.S. 78 (1987)).

221. Id. 
Justice Thomas then proceeded to identify a series of objections to the Court's decision: it constituted a disregard of the democratic process, ${ }^{222}$ it posed a threat to religious liberty, ${ }^{223}$ and it failed in its basic objective of advancing the dignity of same-sex couples because the government is incapable of bestowing dignity which is conferred by the Creator. ${ }^{224}$

\section{Dissent of Justice Alito}

1. Objection to Same-Sex Marriage.-Justice Alito's dissent (joined by Justice Scalia and Justice Thomas) directly challenged the claim of a constitutional right to same-sex marriage and suggested there may be good reasons for not permitting same-sex marriage. ${ }^{225}$ The other dissents were silent on the issue of the social interests challenged by the establishment of same-sex marriage. Justice Alito saw real social harm from recognizing same-sex marriage. ${ }^{226}$ Moreover, Justice Alito did not accept the majority's definition of the right at stake; instead Justice Alito adopted the view that the claim of right to be examined was the "right to same-sex marriage." 227

Justice Alito began by expressing the view that the subject of same-sex marriage was properly one of public debate and it was not an issue for resolution through judicial interpretation of the Constitution. ${ }^{228} \mathrm{He}$ asserted that the Constitution had nothing to say about same-sex marriage and there was no basis for finding the "right to same-sex marriage" as a liberty deeply rooted in history and tradition. ${ }^{229}$

In analyzing the majority's finding that the state has no valid reason for denying same-sex couples access to marriage, Justice Alito challenged the majority's understanding of marriage. ${ }^{230}$ For Justice Alito, procreation is an essential aspect of the institution of marriage, and it was a great error for the majority to dismiss the significant instrumental relation between marriage and procreation along with child rearing. ${ }^{231}$ According to Justice Alito, the majority was mistaken in its view: "the fundamental purpose of marriage is to promote the well-being of those who choose to marry" ${ }^{232}$ and that the value of marriage lies in the fact that it "provides emotional fulfillment and the promise of support in

222. Id. at $2637-38$.

223. Id. at 2638-39.

224. Id. at 2639-40. According to Justice Thomas: "One's liberty, not to mention one's dignity, was something to be shielded from — not provided by - the State." Id.

225. See id. at 2640-43 (Alito, J., dissenting).

226. Id. at 2641.

227. Id. at 2640.

228. Id.

229. Id.

230. Id. at 2641.

231. Id.

232. $I d$. 
times of need." 233 According to Justice Alito, the majority was clearly wrong by narrowly focusing on the "happiness of the persons who choose to marry" rather than recognizing that marriage provides a protected place for procreation and child rearing. ${ }^{234}$ Thus, Justice Alito concluded that the central feature of marriage was ignored by the majority. ${ }^{235}$ According to Justice Alito, civil marriage was established "to encourage potentially procreative conduct to take place within a lasting unit that has long been thought to provide the best atmosphere for raising children." ${ }^{236}$

2. Harms Resulting from Same-Sex Marriage.-According to Justice Alito, there has been a destructive disintegration of the link between marriage and procreation. ${ }^{237} \mathrm{He}$ expressed concern that forty percent of all children born in the United States are born to unmarried women. ${ }^{238}$ According to Justice Alito, it was reasonable to fear that recognition of same-sex marriage will further weaken the bond between marriage and procreation. ${ }^{239}$ While conceding that there may be reasonable debate on this issue, Justice Alito endorsed the view that judges do not have the expertise to resolve the dispute on whether recognition of same-sex marriage will have negative effect on traditional marriage. ${ }^{240}$ Instead, he argued the Court, by an act of usurpation of the democratic process, arrogated to itself the authority to discount the potential negative aspects of same-sex marriage and to legitimize same-sex marriage. ${ }^{241}$

As was done in the other dissents, Justice Alito identified a series of concerns about the implications of the Court's decision, including challenges to religious liberty, the undermining of federalism as the authority of the states is marginalized, the lack of judicial restraint posing a danger to democracy, and the "corruption of our legal culture's conception of constitutional interpretation."242

\section{CONCLUSION}

Obergefell v. Hodges is a landmark civil liberties decision. The decision establishes that there is a fundamental right to marry to which same-sex couples

\footnotetext{
233. $I d$.

234. Id.

235. Id.

236. $I d$.

237. $I d$.

238. Id.

239. Id. at 2641-42.

240. Id. at 2642 .

241. Id.
}

242. Id. at 2642-43. An issue not expressed in his opinion but raised by Justice Alito in oral argument, was whether, given the reliance on the precedent on inter-racial marriage for finding a right to same-sex marriage, the Internal Revenue Service would require the churches, schools, and other charitable associations not to discriminate against individuals in a same-sex marriage if they are to receive the federal income tax exemption of $\S 501(\mathrm{c})(3)$ since private associations that discriminate on the basis of race do not receive such exemptions. 
have a legal right to access. ${ }^{243}$ While recognizing that traditional marriage involved a union of a man and a woman, the Court identified this as an aspect of traditional marriage which is open to change as society has come to accept the validity of same-sex couple relationships. ${ }^{244}$ The Court analyzed the claim to access to marriage as involving the Fourteenth Amendment's Due Process Clause and Equal Protection Clause. ${ }^{245}$ It was the Court's view that the Due Process Clause is not limited to procedural justice, as it also involves substantive due process, which guarantees not only liberties provided explicitly in the text of the Constitution, but also includes liberties that extend to certain personal choices central to individual dignity and autonomy. ${ }^{246}$

According to the Court, the Due Process Clause and Equal Protection Clause are connected in that liberty and equal protection lead to a stronger understanding of each other ${ }^{247}$ The Due Process Clause established that there is a liberty interest of same-sex couples to have access to the fundamental right to marry. ${ }^{248}$ The Equal Protection Clause required the state to license and recognize same-sex marriage because there is no justification for exclusion of same-sex couples from the benefits provided to married couples. ${ }^{249}$ The proffered justification of the ability to procreate as an essential qualification for marriage was rejected since the sterile, women of post-child bearing age, and bed ridden are able to marry. ${ }^{250}$ The Court held that the right to marry was a fundamental right inherent in the liberty of the person under the Due Process and Equal Protection Clauses of the Fourteenth Amendment, and couples of the same-sex may not be deprived of that right and that liberty. ${ }^{251}$

Dissenting justices objected to the resolution of the debate on same-sex marriage by the Court rather than through the democratic process ${ }^{252}$ The dissents maintained there was no basis in the Constitution for finding a right to same-sex marriage. ${ }^{253}$ They faulted the majority for failing to adhere to the established method of substantive due process which would preclude finding a right to "same-sex marriage" established by history and tradition. ${ }^{254}$ They also faulted the majority for not adhering to the established methodology for resolving equal protection claims by failing to identify a class subject to discrimination and a heightened level of scrutiny to determine whether there was justification for the

243. See id. at 2584 (majority opinion).

244. Id. at 2607-08.

245. Id. at 2602-04.

246. Id. at $2597-98$.

247. Id. at 2602-03.

248. Id. at 2599.

249. Id. at 2601-02.

250. Id. at 2601 .

251. Id. at 2604-05.

252. Id. at 2624-25 (Roberts, C.J., dissenting).

253. Id. at 2643 (Alito, J., dissenting).

254. Id. at 2616 (Roberts, C.J., dissenting). 
state's discrimination. ${ }^{255}$ Some dissenting justices expressed concern that samesex marriage would weaken traditional marriage. ${ }^{256}$ Other expressed concern for likely conflict with those asserting rights as same-sex married couples and those invoking religious liberty or right of conscience. ${ }^{257}$

The decision in Obergefell guarantees gays and lesbians all the rights and protections associated with marriage. However, the opinion in Obergefell provides no explicit authority for further claims to rights by homosexuals (gays and lesbians). There was little attention to establishing a class subject of discrimination thus eligible to make claims for other rights or protections. The majority does refer to the "immutable nature" of the individuals who relate as a same-sex couple. ${ }^{258}$ The issue of "immutable characteristic" has often been a part of analyzing a class seeking rights or protections under the Equal Protection Clause and may play a role, as gays and lesbians invoke the Equal Protection Clause as a bar to discrimination or denial of other liberties. Although the opinion in Obergefell does not provide significant legal authority for further development of gay and lesbian rights, the mere fact that gays and lesbians may marry establishes their position in civil society, which is likely to lead in the future to full integration of gays and lesbians into society with all the rights and obligations of citizens.

255. Id. at 2623 .

256. Id. at 2642 (Alito, J., dissenting).

257. Id. at 2638 .

258. Id. at 2594 (majority opinion). 